Tersedia online di: http://ejournal-balitbang.kkp.go.id/index.php/bawal
e-mail:bawal.puslitbangkan@ gmail.com
BAWAL wIDYA RISET PERIKANAN TANGKAP
Volume 11 Nomor 3 Desember 2019
p-ISSN: 1907-8226
e-ISSN: 2502-6410
BAWAL
Nomor Akreditasi Kementerian RISTEKDIKTI: 21/E/KPT/2018

\title{
ASPEK BIOLOGI DAN DINAMIKA POPULASI IKAN LAYANG BIRU (Decapterus macarellus Cuvier, 1833) DI PERAIRAN LAUT SULAWESI
}

\section{BIOLOGIAL ASPECTS AND POPULATION DYNAMICS OF MACKEREL SCAD (Decapterus macarellus CUVIER, 1833) IN THE WATERS OF CELEBES SEA}

\author{
Achmad Zamroni $^{1}$, Adi Kuswoyo ${ }^{2}$ dan Umi Chodrijah ${ }^{1}$ \\ ${ }^{1}$ Peneliti dari Balai Riset Perikanan Laut, Cibinong, Komp. Raiser Ikan Hias, Jl. Raya Bogor KM. 47 Nanggewer Mekar, Cibinong, \\ Bogor Jawa Barat, Indonesia \\ ${ }^{2}$ Teknisi litkayasa dari Balai Riset Perikanan Laut, Cibinong, Komp. Raiser Ikan Hias, Jl. Raya Bogor KM. 47 Nanggewer Mekar, \\ Cibinong, Bogor Jawa Barat, Indonesia \\ Teregistrasi I tanggal: 25 September 2019; Diterima setelah perbaikan tanggal: 20 Januari 2020; \\ Disetujui terbit tanggal: 28 Januari 2020
}

\begin{abstract}
ABSTRAK
Ikan layang biru (Decapterus macarellus) merupakan salah satu jenis ikan pelagis kecil yang dominan tertangkap dan mempunyai nilai ekonomi yang tinggi, terutama untuk daerah dengan perairan yang lebih oseanik seperti di perairan Indonesia bagian timur. Tujuan penelitian ini adalah untuk mengidentifikasi parameter populasi ikan layang biru khususnya tertangkap di Laut Sulawesi. Pengambilan sampel ikan untuk diukur panjang cagak dan diamati kematangan gonad dilakukan secara acak setiap bulan. Informasi parameter populasi yang diperoleh dalam penelitian ini adalah hubungan panjang-berat, nisbah kelamin, tingkat kematangan gonad, nilai L50\% dan Lm, parameter pertumbuhan serta tingkat pemanfaatan. Hasil penelitian menunjukkan bahwa sebaran ukuran panjang cagak ikan (fork length $=\mathrm{FL}$ ) berkisar antara 10,25 $-32,25 \mathrm{~cm}$, pola pertumbuhannya bersifat allometrik negatif. Nisbah kelamin ikan layang biru antara jantan : betina tidak berimbang yaitu $1: 1,963$. Ikan layang biru yang tertangkap didominasi oleh ikan dalam kondisi kematangan gonad tingkat III, artinya gonad masih dalam kondisi berkembang. Berdasarkan analisis tingkat kematangan gonad dan nilai indeks gonad dapat diketahui bahwa puncak musim pemijahan ikan terjadi pada bulan Maret. Perbandingan nilai L50\% dan Lm diperoleh (L50\% > Lm), artinya secara umum ikan telah mengalami matang gonad sebelum ikan tersebut ditangkap. Nilai eksplotasi lebih tinggi dari nilai eksploitasi optimal 0,5 per-tahun. Diduga puncak rekruitmen yang terjadi pada bulan Juni berasal dari musim pemijahan yang terjadi pada bulan Maret.
\end{abstract}

Kata Kunci: Layang biru; dinamika populasi; kematangan gonad; Laut Sulawesi

\section{ABSTRACT}

Mackerel scad (Decapterus macarellus) is one of the dominant small pelagic fish species with high economic value, especially for areas with more oceanic waters such as eastern Indonesia. The purpose of this study was to identify the population parameters of the Mackerel scad especially those caught in the Celebes Sea. Fish samples were randomly taken to measure for length measurements and gonad maturity observation every month. Information on population parameters obtained in this study is the length-weight relationship, sex ratio, gonad maturity level, L50\% and Lm values, growth parameters, and exploitation rates. The results showed that the distribution of fish length range from 10.25 - $32.25 \mathrm{~cm}$ offork length, with the growth pattern was negative allometric. The sex ratio between males: females was not balanced (1: 1,963). The Mackerel scad caught was dominated by fish in the condition of level III maturity, meaning that each gonad was in a developing condition. Based on the analysis of gonad maturity and gonad index, it can be estimated that the peak of the spawning season occurs in March. A comparison of the values of L50\% and Lm obtained was L50\% > Lm, meaning that in general, the fish has reached gonad ripening before they were caught. The exploitation rate was higher than the optimal exploitation value of 0.5 per year. It is likely that the peak of recruitment occurred in June came from the spawning season occurred in March.

Keywords: Mackerel scad; population dynamic; gonad maturity; Celebes sea

Korespondensi penulis:

e-mail:ironzammiden@gmail.com

Telp. +62 812-1088-3373

DOI: http://dx.doi.org/10.15578/bawal.11.1.2019.137-149

Copyright (C) 2019, BAWAL WIDYA RISET PERIKANAN TANGKAP (BAWAL) 


\section{PENDAHULUAN}

Berdasarkan data statistik perikanan tangkap nasional tahun 2016 untuk perairan Wilayah Pengelolaan Perikanan Negara Republik Indonesia (WPP NRI 716) (perairan Laut Sulawesi) tercatat ikan layang biru (Decapterus macarellus) mempunyai prosentase hasil tangkapan sebanyak 24\% (sekitar 33.000 ton) dari total hasil tangkapan komoditas ikan pelagis kecil. Terdapat beberapa pusat pendaratan ikan layang biru di WPP NRI 716 antara lain di Pelabuhan Perikanan Pantai (PPP) Tumumpa, Kota Manado. Berbeda dengan PPS Bitung, hasil tangkapan nelayan di PPP Tumumpa hanya berasal dari WPP NRI 716, sedangkan hasil tangkapan nelayan di PPS Bitung bisa berasal dari WPP NRI 715, 716 dan 717. Hasil tangkapan ikan layang biru di PPP Tumumpa dari tahun 2013 hingga tahun 2018 adalah lebih dari $90 \%$ dari total hasil tangkapan komoditas ikan pelagis kecil. Berdasarkan data tersebut dapat diketahui bahwa ikan layang biru merupakan jenis ikan yang mempunyai peran penting dalam perikanan baik skala menengah maupun industri di perairan WPP NRI 716. Selain sebagai ikan konsumsi, ikan layang biru juga mempunyai nilai ekspor, yaitu dimanfaatkan sebagai umpan bagi penangkapan tuna long line.

Monitoring hasil tangkapan yang dilakukan oleh PPP Tumumpa menunjukkan bahwa jumlah unit armada pukat cincin semakin meningkat. Pada tahun 2013 jumlah armada pukat cincin yang beroperasi berjumlah sekitar 58 unit, pada tahun 2018 jumlah ini meningkat menjadi 85 unit. Hal ini berimplikasi pada nilai laju tangkap dari tahun 2017 sampai tahun 2018 yang mengalami penurunan yaitu dari sekitar 30 ton/unit menjadi sekitar lebih dari 15 ton/unit. Peningkatan armada dan penurunan laju tangkap merupakan salah satu dugaan bahwa ikan layang biru telah mengalami lebih tangkap. Salah satu penyebab meningkatnya jumlah armada adalah meningkatnya permintaan akan ikan layang biru. Menurut Widodo \& Suadi (2006), semakin meningkat tuntutan pemenuhan sumberdaya ikan maka tekanan eksploitasi sumberdaya ikan juga semakin meningkat. Pemanfaatan secara berlebih dikhawatirkan dapat menyebabkan kehancuran pada usaha perikanan jika tidak dikelola secara baik dan bijaksana. Akan tetapi informasi yang lebih detail mengenai status sumberdaya ikan berdasarkan parameter biologinya (idetifikasi kematangan gonad dan dinamika populasi) masih belum memadai.

Parameter biologi reproduksi misalnya ukuran saat matang gonad adalah parameter kunci dari life history dalam manajemen perikanan yang telah mengalami eksploitasi (Watters \& Hobday, 1998). Hal yang sangat penting adalah bahwa individu dalam populasi harus dilindungi, sehingga mereka mempunyai kesempatan untuk melakukan reproduksi sebelum mereka mencapai ukuran tangkapan yang diperbolehkan atau masuk dalam perikanan (Donaldson \& Donaldson, 1992). Stearns (1992) menyatakan bahwa ukuran ikan saat kematangan gonad sangat penting dalam konteks strategi reproduksi dan eksplotasi. Secara umum, ukuran ikan yang besar pada saat kematangan gonad mempunyai potensi yang baik dalam hal reproduksi. Berdasarkan Pollock (1995) menyebutkan bahwa tekanan perikanan yang tinggi dapat mereduksi ukuran ikan saat kematangan gonad. Populasi ikan merespon eksploitasi dengan terjadinya penurunan ukuran pada saat matang gonad yang disebabkan oleh peningkatan kematian (Jørgensen et al., 2007).

Untuk itu perlu dilaksanakan penelitian mengenai identifikasi kematangan gonad dan dinamika populasi ikan layang biru di perairan Laut Sulawesi yang merupakan bagian dari WPP NRI 716. Diharapkan hasil penelitian ini dapat dimanfaatkan sebagai acuan pertimbangan dalam pengelolaan sumberdaya ikan yang berkelanjutan dan sebagai upaya dalam pengawasan stok ikan layang biru. Penelitian ini bertujuan untuk mengidentifikasi aspek biologi ikan layang biru di Laut Sulawesi meliputi hubungan panjang-berat, nisbah kelamin, tingkat kematangan gonad (TKG), panjang ikan pertama kali matang gonad (Lm) dan panjang ikan rata-rata tertangkap (L50\%), serta untuk mengetahui aspek dinamika populasi ikan layang biru yang meliputi parameter pertumbuhan, rekruitmen dan mortalitas sehingga dapat ditentukan laju eksploitasi beserta status pemanfaatannya.

\section{BAHANDANMETODE Pengambilan Sampel}

Pengambilan sampel ikan layang biru dilakukan di Pelabuhan Perikanan Pantai (PPP) Tumumpa, Kota Manado, Sulawesi Utara, yang termasuk dalam Wilayah Pengelolaan Perikanan Republik Indonesia (WPP RI) 716 (Gambar 1). Sampel ikan layang biru diambil dari hasil tangkapan armada penangkap pukat cincin yang beroperasi di Laut Sulawesi. Pengambilan sampel dilakukan setiap bulan dari Januari hingga November. Armada penangkap pukat cincin yang mendarat di PPP Tumumpa dilengkapi oleh GPS. Panjang jaring yang digunakan sekitar $450 \mathrm{~m}$ dengan ukuran mata jaring bagian kantong 1 inch.

Sampling ikan dilakukan secara acak sehingga dapat mewakili populasi dan stok ikan di perairan Laut Sulawesi. Pengumpulan data dari sampel ikan meliputi panjang cagak (Fork length/FL) yang diukur dengan alat pengukur panjang ikan dengan ketelitian $1 \mathrm{~mm}$, penimbangan bobot ikan menggunakan timbangan dengan ketelitian $0,1 \mathrm{~g}$ dan dilakukan pembedahan tubuh ikan atau perut ikan untuk mengetahui jenis kelamin, tingkat kematangan gonad serta berat gonad.

Analisis tingkat kematangan gonad (TKG) dilakukan dengan mengamati secara visual pada gonad sampel ikan 
layang biru. Penentuan tingkat kematangan gonad mengacu pada "Skala Kematangan Gonad Standard"
(Five-point maturity scale for partial spawners) berdasarkan Cassie dalam Effendie (2002) (Tabel 1).

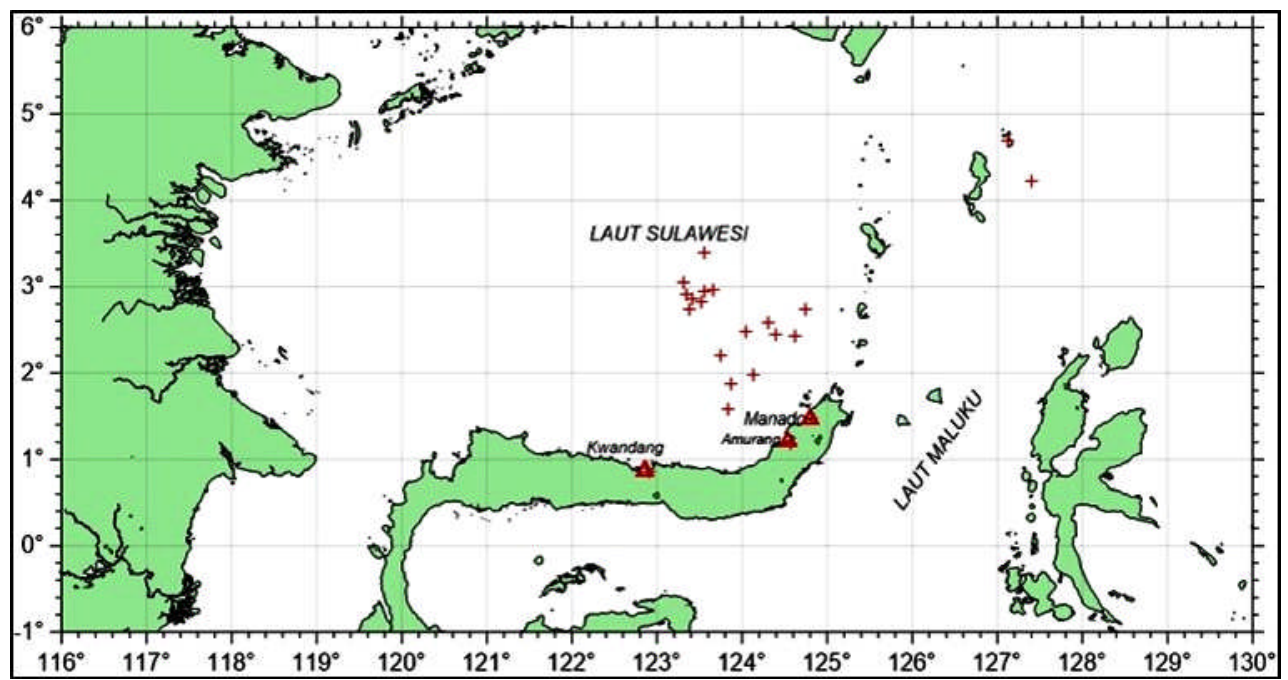

Gambar 1. Lokasi pengambilan sampel ikan layang biru dan prediksi daerah penangkapan pukat cincin yang berbasis di Tumumpa, Kota Manado.

Figure 1. Sampling location of Macekerel scad and fishing ground predictions of purse seine from Tumumpa, Manado.

Tabel 1. Tingkat kematangan gonad ikan

Tabel 1. Gonad maturity of fish

\begin{tabular}{|c|c|c|}
\hline $\begin{array}{c}\text { Tingkat } \\
\text { Kematangan }\end{array}$ & Betina & Jantan \\
\hline I & $\begin{array}{l}\text { Ovari seperti benang, panjang sampai } \\
\text { kedepan rongga tubuh. Warna jernih. } \\
\text { Permukaan licin. }\end{array}$ & $\begin{array}{l}\text { Testes seperti benang, lebih pendek } \\
\text { (terbatas) dan terlihat ujung-ujungnya di } \\
\text { rongga tubuh. Warna jernih. }\end{array}$ \\
\hline II & $\begin{array}{l}\text { Ukuran ovary lebih besar. Pewarnaan lebih } \\
\text { gelap kekuning-kuningan. Telur belum } \\
\text { terlihat jelas dengan mata. }\end{array}$ & $\begin{array}{l}\text { Ukuran testes lebih besar. Pewarnaan putih } \\
\text { seperti susu. Bentuk lebih jelas pada tingkat } \\
\text { I. }\end{array}$ \\
\hline III & $\begin{array}{l}\text { Ovary berwarna kuning, secara morfologi } \\
\text { telur mulai kelihatan butirnya dengan mata. }\end{array}$ & $\begin{array}{l}\text { Permukaan testes tampak bergerigi. Warna } \\
\text { makin putih, testes makin besar. Dalam } \\
\text { keadaan awet mudah putus. }\end{array}$ \\
\hline IV & $\begin{array}{l}\text { Ovary makin besar, telur berwarna kuning, } \\
\text { mudah dipisahkan. Butir minyak tidak } \\
\text { tampak, mengisi } 1 / 2-2 / 3 \text { rongga perut, usus } \\
\text { terdesak. }\end{array}$ & $\begin{array}{l}\text { Seperti pada tingkat III tampak lebih jelas. } \\
\text { Testes semakin pejal. }\end{array}$ \\
\hline V & $\begin{array}{l}\text { Ovary berkerut, dinding tebal, butir telur sisa } \\
\text { terdapat didekat pelepasannya. }\end{array}$ & $\begin{array}{l}\text { Testes bagian belakang kempis dan di } \\
\text { bagian dekat pelepasan masih berisi. }\end{array}$ \\
\hline
\end{tabular}

\section{Analisis Data}

Analisi hubungan panjang berat ikan mengacu pada Paully (1984) yaitu:

$\mathrm{W}=\mathrm{a} \cdot \mathrm{L}^{\mathrm{b}}$

Persamaan tersebut diubah ke dalam persamaan linier, $\ln \mathrm{W}=\ln \mathrm{a}+\mathrm{b} \ln \mathrm{L}$

Dimana: $\mathrm{W}=$ berat ikan (gram); $\mathrm{L}=$ panjang tubuhu ikan $(\mathrm{cm}) ;$ ln $\mathrm{a}=$ intercept dan $\mathrm{b}=$ slope

Berdasarkan Effendie (2002), pola pertumbuhan dapat diketahui dari nilai b, yaitu: yaitu: 
$\mathrm{b}=3$ : Isometrik, pertambahan panjangnya sama dengan pertambahan berat.

$\mathrm{b} \neq 3$ : Allometrik. Jika $\mathrm{b}>3$ alometrik positif, dan jika $\mathrm{b}$ $<3$ allometrik negatif.

Uji t dilakukan pada nilai b untuk mengetahui sifat pertumbuhan suatu ikan dirumuskan sebagai berikut (Sokal \& Rohlf, 1987):

$t_{s}=\frac{b-a}{S_{b}}$

Dimana: $\mathrm{t}_{\mathrm{s}}=$ hasil $\mathrm{t}$ hitung; $\mathrm{b}=$ slope dan $\mathrm{S}_{\mathrm{b}}=$ standard error slope (b)

Penghitungan nisbah kelamin menggunakan cara yang sesuai dengan Ambarwati (2008) sebagai berikut:

$$
X=\frac{J}{B}
$$

Dimana: $\mathrm{X}=$ nisbah kelamin; $\mathrm{J}=$ jumlah ikan jantan (ekor) dan B = jumlah ikan betina (ekor).

Nilai yang baik (ideal) adalah nisbah kelamin berada pada keadaan seimbang, atau ikan betina lebih banyak daripada ikan jantan (jantan : betina $=1: \geq 1)($ Ball \& Rao, 1984; Wahyuono et al., 1983).

Analisis indeks kematangan gonad menggunakan persamaan yang diuraikan dalam Effendie (2002), sebagai berikut:

$I K G=\frac{B_{g}}{B_{t}} \times 100 \%$

Dimana: $\mathrm{IKG}=$ Indeks kematangan gonad; $\mathrm{B}_{\mathrm{g}}=$ berat gonad dan $\mathrm{B}_{\mathrm{t}}=$ berat ikan.

Pendugaan ukuran pertama matang gonad (length at first maturity/Lm) dilakukan dengan mengacu prosedur Sperman - Karber yang dilakukan Udupa (1986) melalui perhitungan nilai logaritma pertambahan kumulatif nilai tengah sebagai berikut:

$m=X_{k}+\frac{x}{2}-\left(X \sum_{i=\rho i}^{n}\right)$

Dimana: $\mathrm{m}=$ logaritma panjang pertama matang gonad; $\mathrm{X}_{\mathrm{k}}=$ logaritma kelas panjang ukuran pada saat $100 \%$ matang gonad; $\mathrm{X}=$ selisih logaritma dari pertambahan nilai tengah panjang dan $\mathrm{p}_{\mathrm{i}}=$ proporsi matang gonad pada kelompok ukuran ke-i. Panjang pertama kali matang gonad diperoleh dengan mengantilogkan nilai $\mathrm{m}$.
Panjang pertama kali tertangkap (length at first capture, $\mathrm{L}_{\mathrm{c}}$ ) diperoleh dari metode Beverton \& Holt dalam Sparre \& Venema (1998):

$$
S L=\frac{1}{1+\exp (a-b L)}
$$

Dimana nilai dari a (intercept) dan b (slope) diperoleh dari persamaan regresi linear sebagai berikut:

$\operatorname{Ln}\left(\frac{1}{S L_{c}}-1\right)=a-b L$

Dimana SL = estimasi nilai panjang; $\mathrm{L}=$ nilai tengah panjang $(\mathrm{cm}) ; \mathrm{SL}_{\mathrm{c}}=$ frekuensi panjang relatif kumulatif. Nilai $L_{c}$ dapat diperoleh dari persamaan:

$\mathrm{Lc}=-\mathrm{a} / \mathrm{b}$

Koefisien pertumbuhan (K) dan panjang maksimum/ panjang asimptotik $\left(\mathrm{L}_{\infty}\right)$ ikan diperoleh berdasarkan Von Bertanlanffy Growth Function (VBGF). Parameter pertumbuhan tersebut didapatkan dengan menggunakan perangkat lunak R-Program versi 3.6.1 dengan paket TropFishR. Menurut VBGF, rata-rata pertumbuhan ikan menuju panjang maksimum pada koefesien pertumbuhan (K) dan dengan panjang pada waktu (t) berdasarkan persamaan berikut (Sparre \& Venema, 1998):

$\mathrm{Lt}=\mathrm{L} \infty\left[1-\mathrm{e}^{-\mathrm{K}(\mathrm{t}-\mathrm{to})}\right]$

Dimana: $\mathrm{Lt}=$ panjang saat umur $\mathrm{t}(\mathrm{cm}) ; \mathrm{L}_{\infty}=$ panjang asimptotik $(\mathrm{cm}) ; \mathrm{K}=$ koefisien pertumbuhan $\left(\mathrm{yr}^{-1}\right)$; dan $\mathrm{t}_{0}$ $=$ umur teoritis saat panjang ikan nol (0)

Umur teoritis saat ikan lahir $\left(\mathrm{t}_{0}\right)$ dihitung berdasarkan persamaan empiris (Pauly, 1984):

$\log \left(-\mathrm{t}_{0}\right)=-0.392-0.275 \log \mathrm{L}_{\infty}-1.038 \log \mathrm{K}$

Koefisiesn mortalitas total $(Z)$ diperoleh dengan menggunakan analisis linearized length-converted catch curve (Sparre \& Venema, 1998). Mortalitas alami dapat diduga dengan menggunakan (Pauly, 1980):

$\log M=-0.0066-0.279 \log L_{\infty}+0.6543 \log K+0.4634$ $\log \mathrm{T}$

Dimana, $\mathrm{M}=$ mortalitas alami dan; $\mathrm{T}$ = rata-rata suhu air laut $\left({ }^{\circ} \mathrm{C}\right)$

Mortalitas penangkapan (F) dapat diduga dengan menggunakan hubungan (Ricker, 1975 in Sparre \& Venema, 1998):

$\mathrm{Z}=\mathrm{F}+\mathrm{M}$ 
Laju eksploitasi (E) ditentukan dengan membandingkan laju mortalitas penangkapan $(\mathrm{F})$ dengan laju mortalitas total (Z) (Pauly,1984):

$$
E=\frac{F}{F+M}=F / M
$$

\section{HASIL DAN BAHASAN Hasil}

\section{Struktur Ukuran Ikan}

Struktur ukuran panjang cagak ikan layang biru disajikan pada pada Gambar 2. Dari hasil sampel sebanyak
4.480 ekor diperoleh kisaran panjang cagak (FL) ikan layang biru antara $10,75-32,75 \mathrm{~cm}$, dengan modus $24,75 \mathrm{~cm}$.

\section{Hubungan Panjang-Berat}

Hubungan panjang cagak dan berat ikan layang biru berdasarkan 1.321 sampel diperoleh nilai koefisien nilai a $=0,0318 ;$ nilai $\mathrm{b}=2,7461\left(\mathrm{R}^{2}=0,8994\right)$. Uji komparatif terhadap koefisien bentuk tubuh (b) didapatkan nilai kurang dari $3\left(t_{\text {hit }}=9,03 ; p>0,05\right)$. Hasil ini menunjukkan pola pertumbuhan ikan layang biru bersifat allometrik negatif yaitu pertambahan berat lebih lambat dibanding pertambahan panjangnya. Grafik hubungan panjang-berat ikan layang biru dijelaskan pada Gambar 3 .

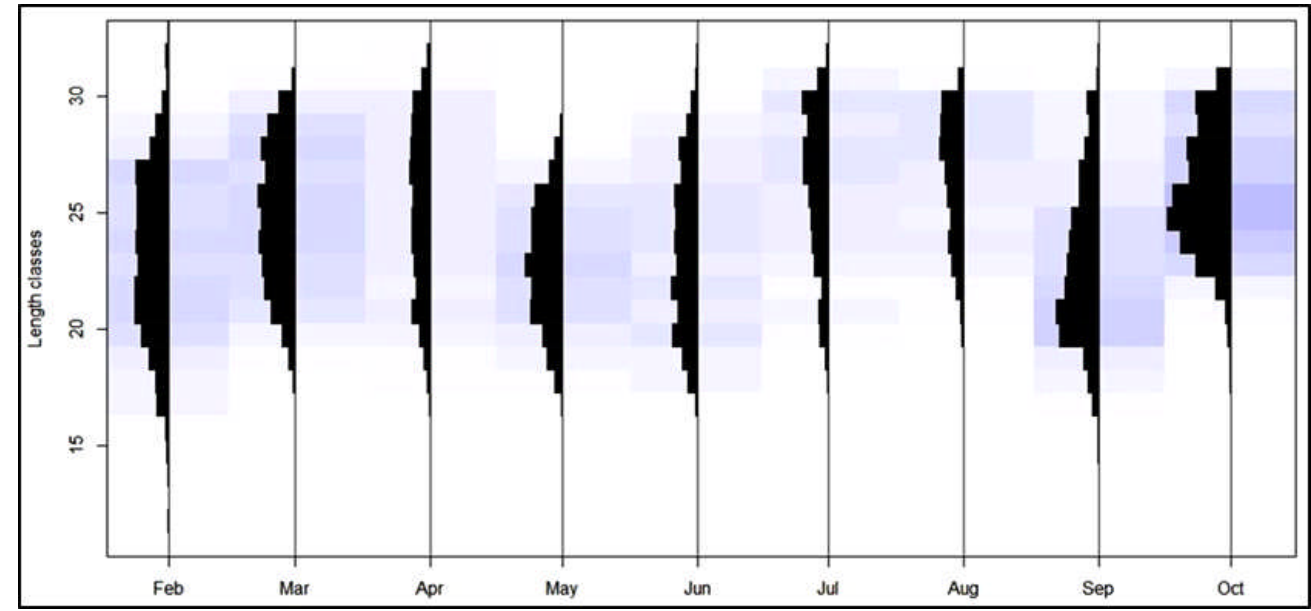

Gambar 2. Distribusi frekuensi panjang cagak (FL) ikan layang biru hasil tangkapan pukat cincin di Laut Sulawesi. Figure 2. Fork length (FL) frequency distribution of Mackerel scad caught by purse seine in Sulawesi Sea.

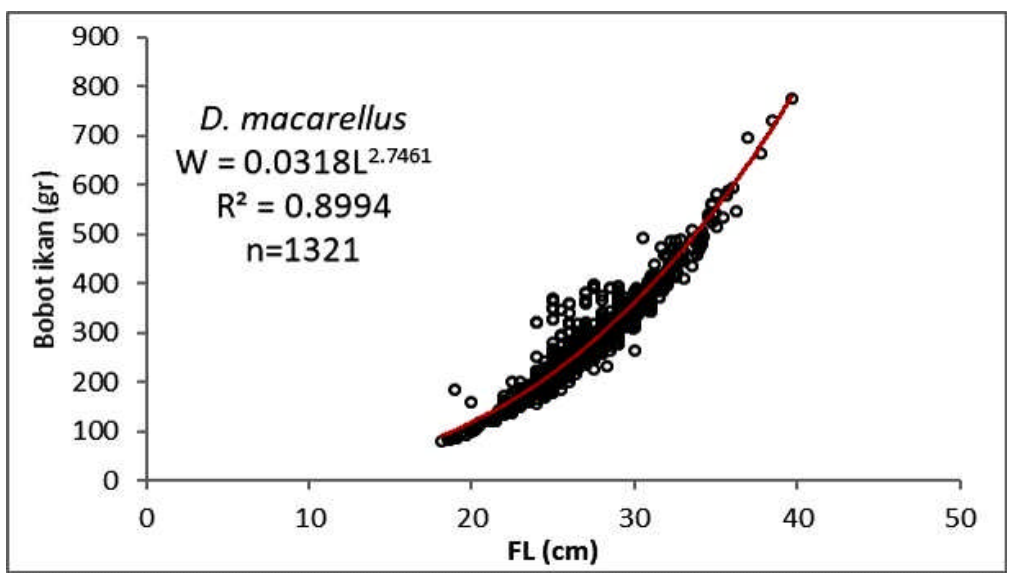

Gambar 3. Hubungan panjang dan berat ikan layang biru di perairan Laut Sulawesi.

Figure 3. Length-weight relationships of Mackerel scad in Sulawesi Sea.

\section{Nisbah Kelamin}

Dari perbandingan jenis kelamin ikan layang biru diperoleh rasio jantan : betina yang berbeda pada setiap bulannya. Secara keseluruhan, perbandingan kelamin ikan layang biru jantan dan betina adalah 1,963:1 (Gambar 4).

\section{Tingkat Kematangan Gonad (TKG)}

Hasil pengamatan secara visual terhadap gonad sampel ikan layang biru menunjukkan perubahan komposisi TKG tiap bulannya. TKG ini menunjukkan fasefase yang diklasifikasikan menjadi 5 tingkatan (jantan dan betina). Komposisi ikan layang biru betina TKG III dominan pada setiap bulan dan TKG IV hanya pada bulan Februari. 


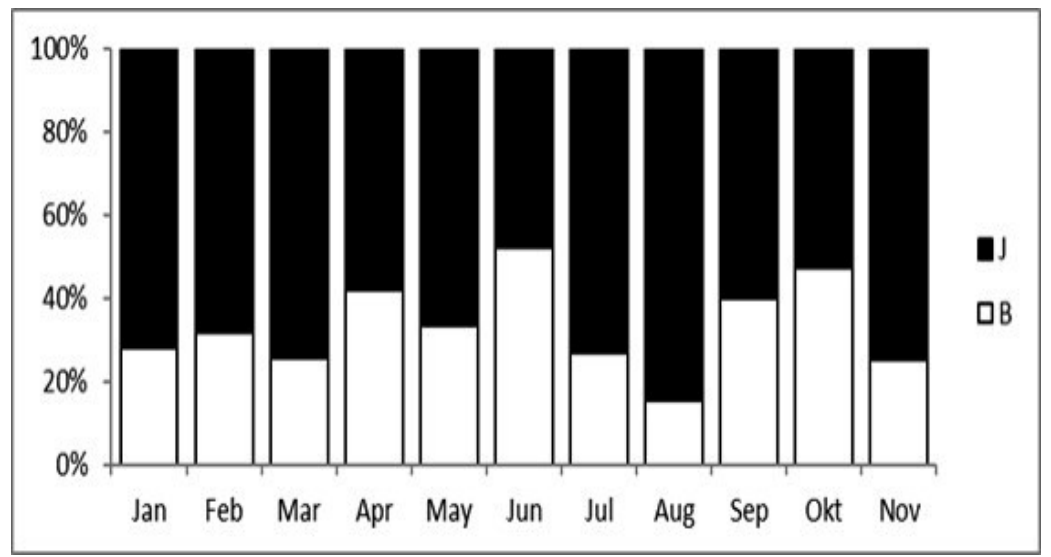

Gambar 4. Perbandingan jenis kelamin ikan layang biru dari perairan Laut Sulawesi.

Figure 4. Sex ratio of Mackerel scad in the Sulawesi Sea.

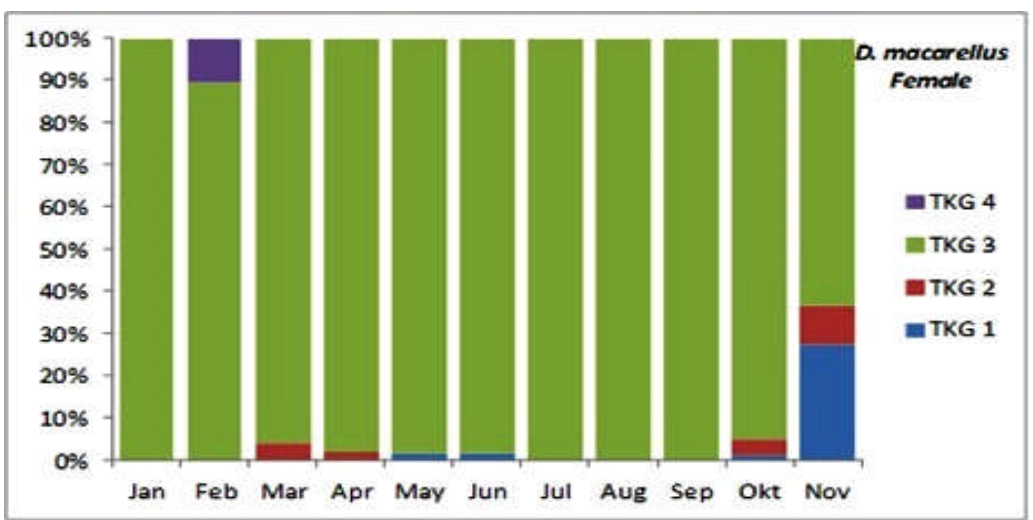

Gambar 5. Tingkat kematangan gonad ikan layang biru di perairan Laut Sulawesi.

Figure 5. Gonad maturity of Mackerel scad in the Sulawesi Sea.

\section{Indeks Kematangan Gonad}

Penghitungan indeks gonad dilakukan dari Januari hingga November, nilai rata-rata indeks gonad yang tertinggi terjadi pada bulan Februari. Bulan-bulan berikutnya nilai rata-rata indeks gonad cenderung mengalami penurunan. Nilai rata-rata indeks gonad yang lebih rendah terjadi pada bulan Maret, Juli dan November (Gambar 6).

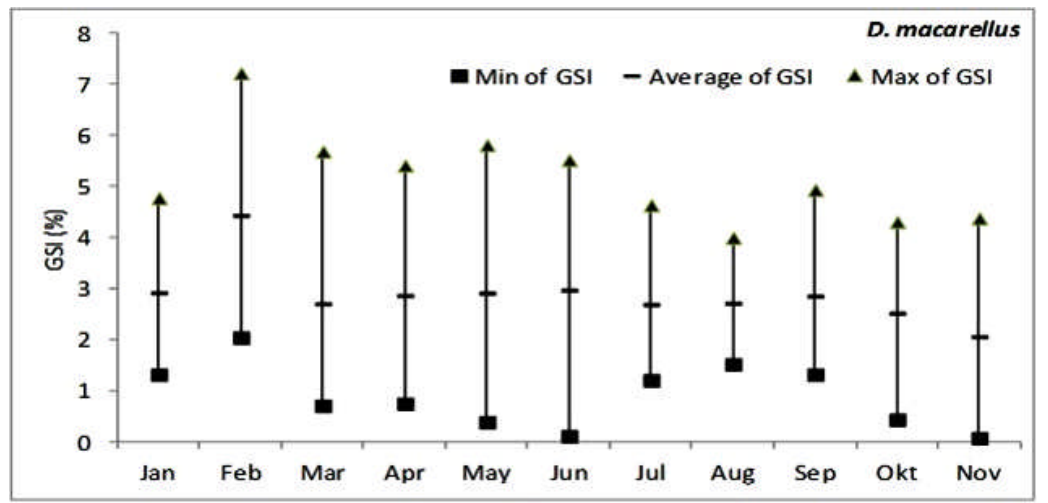

Gambar 6. Indeks gonad ikan layang biru di perairan Laut Sulawesi.

Figure 6. Gonad index of Mackerel scad in The Sulawesi Sea.

Panjang Pertama Kali Matang Gonad (Lm) dan Ratarata Tertangkap (L50\%)

Dengan menggunakan metode Sperman - Karber yang dilakukan Udupa (1986), nilai panjang pertama kali matang gonad ikan layang biru di perairan Laut Sulawesi adalah pada panjang cagak $20,7 \mathrm{~cm}$. Panjang rata-rata tertangkap (50\% kumulatif) ikan layang biru dengan alat tangkap purse seine (pukat cincin) adalah pada panjang cagak $26,89 \mathrm{~cm}$ (Gambar 7). 


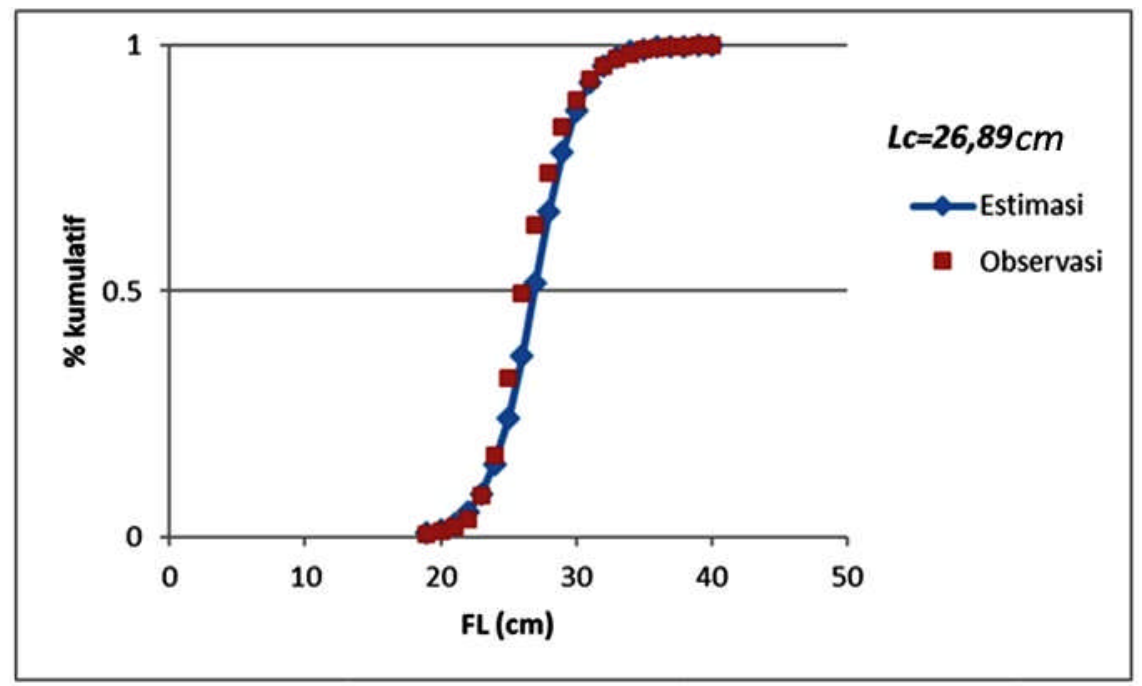

Gambar 7. Panjang rata-rata ikan layang biru yang tertangkap (Lc) dengan alat tangkap pukat cincin di perairan Laut Sulawesi.

Figure 7. Length at first capture (Lc) of Mackerel scad from purse seine.

\section{Parameter Populasi}

Berdasarkan hasil analisis frekuensi panjang cagak ikan layang biru diperoleh panjang asimptotik $\left(\mathrm{L}_{\infty}\right)$ pada panjang cagak $34,5 \mathrm{~cm}$ dengan koefisien pertumbuhan $(\mathrm{K})$ $=0,81$ per-tahun $(\mathrm{Rn}=0,66)$. Hasil analisis mortalitas total (Z) diperoleh nilai 2,34 per tahun. Dengan rata-rata suhu tahunan di perairan Laut Sulawesi $29^{\circ} \mathrm{C}$, maka jika dimasukkan dalam persamaan empiris Pauly (1980) didapatkan mortalitas alami (M) dari ikan layang biru adalah 1,1 per-tahun. Mortalitas penangkapan (F) yang didapatkan dari $\mathrm{F}=\mathrm{Z}-\mathrm{M}$ adalah 1,2 per-tahun dengan rasio eksploitasi (E) yang diperoleh 0,53 pertahun. Grafik Von Bertalanffy Growth dan kurva hasil tangkapan ikan layang biru di perairan Laut Sulawesi tersaji pada Gambar 8 .

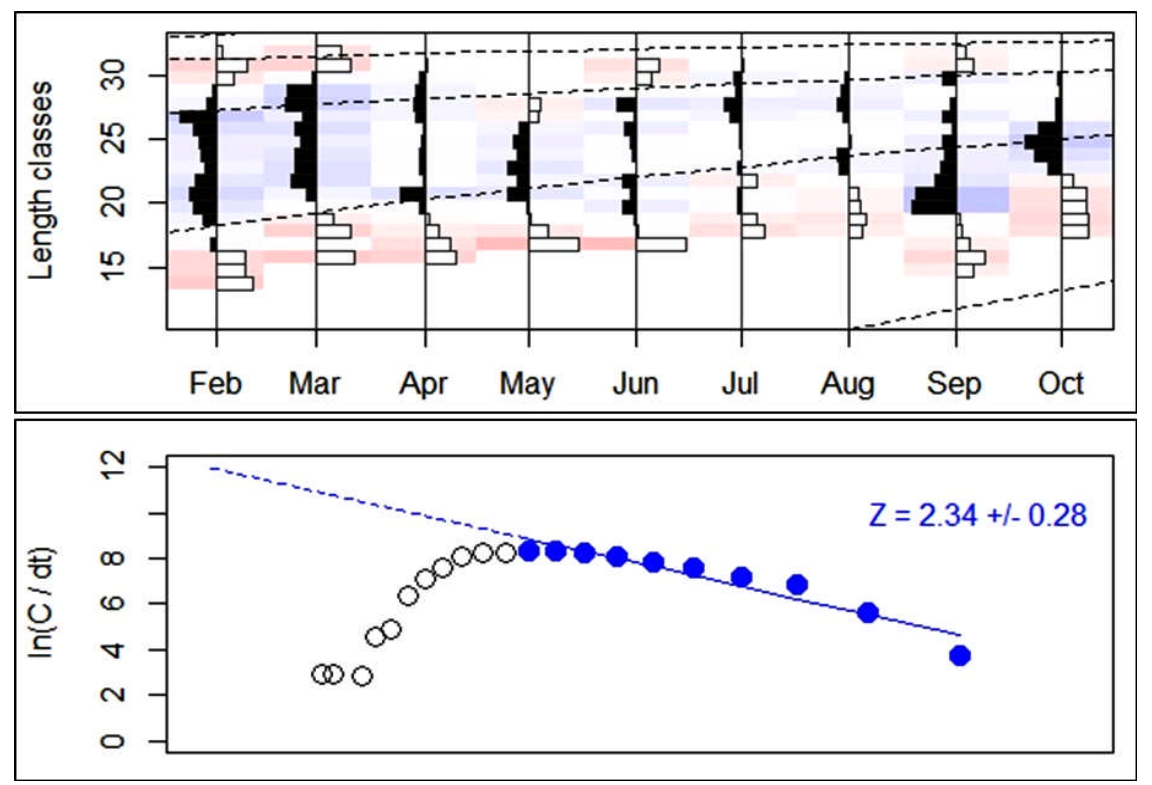

Gambar 8. Estimasi total mortalitas dengan metode catch curve menurut ukuran panjang ikan layang biru di Laut Sulawesi.

Figure 8. Total mortality estimation with catch curve method by length of Mackerel scad in Sulawesi Sea.

Dari panjang infinity ikan layang biru (Decapterus macarellus) $\left(\mathrm{L}_{\infty}\right)$, laju pertumbuhan $(\mathrm{K})$ dan nilai $\mathrm{t}_{0}(-0,138 /$ tahun) dapat diperoleh persamaan pertumbuhan Von
Bertalanffy $\mathrm{Lt}=34,5\left(1-\mathrm{e}^{-0,81(\mathrm{t}-0,123)}\right)$. Dari persamaan yang diperoleh dapat dibuat kurva hubungan antara umur dengan panjang, seperti terlihat pada Gambar 9. 


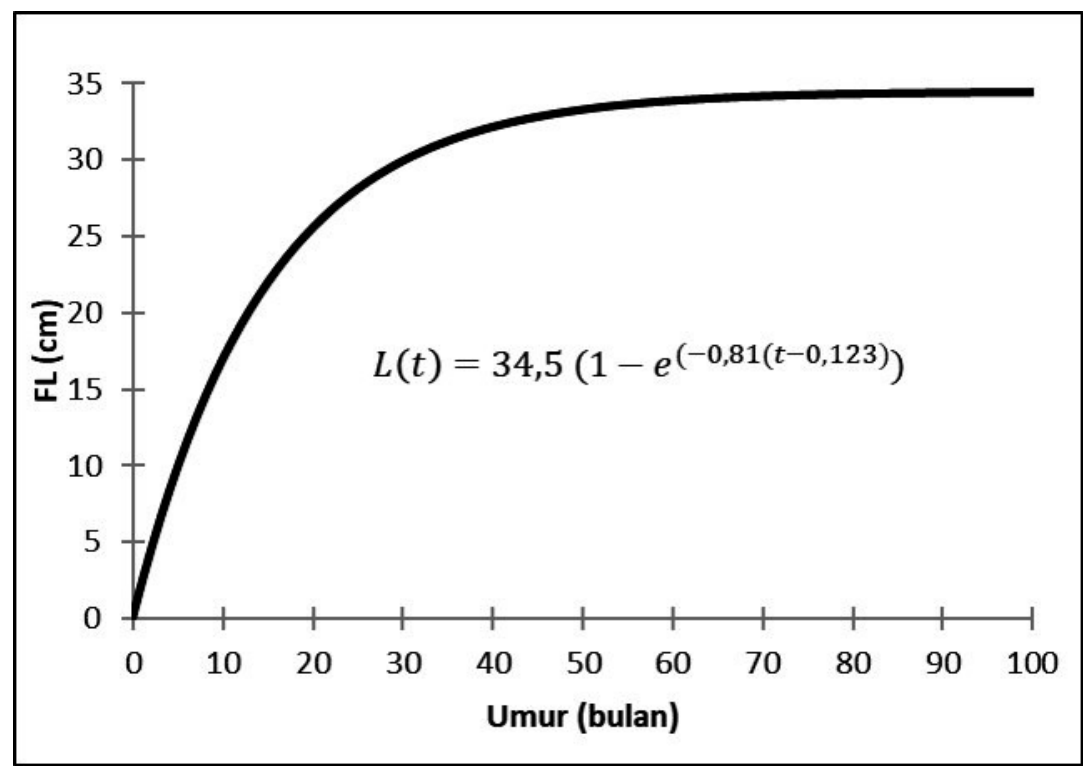

Gambar 9. Kurva Von Bertalanffy hubungan umur dengan panjang ikan layang biru di Laut Sulawesi.

Figure 9. Von Bertalanffy curve of Age and length relationships of Mackerel scad in Sulawesi Sea.

\section{Bahasan}

Sebaran ukuran ikan layang biru yang tertangkap oleh pukat cincin di Tumumpa, Manado mempunyai ukuran yang lebih panjang dibandingkan dengan penelitian yang dilakukan oleh Ongkers et al. (2016) di perairan Latuhalat, Ambon dan Manik (2009) di Teluk Likupang, Sulawesi Utara. Sebaran ukuran ikan layang di perairan Latuhalat, Ambon adalah pada panjang cagak 7,5 - 28,6 cm, sedangkan sebaran ukuran ikan layang di perairan Teluk Likupang, Sulawesi Utara adalah pada panjang cagak 8,4 $-25,2 \mathrm{~cm}$. Kisaran ukuran panjang cagak ikan layang biru di Teluk Tomini adalah pada panjang cagak 17,25 - 30,25 $\mathrm{cm}$ (Widiyastuti \& Zamroni, 2015). Namun penelitian yang dilakukan oleh Hariati (2011) pada spesies ikan yang sama di perairan Kendari mempunyai kisaran ukuran panjang cagak yang lebih panjang, yaitu $14-32 \mathrm{~cm}$. Diduga terdapat beberapa faktor yang menyebabkan sebaran ukuran ikan layang biru di Laut Sulawesi lebih lebar dari penelitian lain, faktor yang pertama adalah yang berhubungan dengan operasional penangkapan pukat cincin nelayan Tumumpa. Lama hari operasi nelayan pukat cincin di Tumumpa sangat bervariasi, berdasarkan informasi dari tenaga lapangan/enumerator lama hari operasi berkisar antara 3 - 10 hari. Variasi lama hari operasi akan berpengaruh terhadap variasi daerah penangkapan yang lebih lebar pula, sehingga hal ini dapat menyebabkan ukuran ikan yang tertangkap menjadi lebih bervariasi. Faktor yang kedua adalah perbedaan ukuran ikan juga dapat dipengaruhi oleh kondisi lingkungan, kelimpahan dan ketersediaan makanan, suhu dan cahaya pada tiap perairan yang berbeda (Nikolsky, 1963). Hal ini didukung oleh kondisi perairan Laut Sulawesi yang dilalui oleh Arus Lintas Indonesia/Arlindo (Indonesian Through Flow/ITF), cabang utama Arlindo di perairan Indonesia berada di Laut
Sulawesi. Arus ini dari Samudera Pasifik hingga ke Samudera Hindia, melalui pintu masuk Laut Sulawesi ke Selat Makassar. Arlindo ini membawa masa air yang kaya akan nutrien dan oksigen, disamping itu juga berperan besar dalam proses distribusi larva berbagai biota di Laut Sulawesi.

Hasil analisis hubungan panjang-berat ikan layang biru pada penelitian ini berbeda dengan hasil penelitian yang dilakukan oleh Wulan et al. (2017) di perairan selatan Blitar yang menyatakan bahwa pola pertumbuhannya bersifat isometrik. Hal yang sama juga terjadi pada hasil penelitian yang dilakukan oleh Akerina et al. (2019) di perairan Likupang, Sulawesi Utara. Akan tetapi penelitian yang dilakukan oleh Manik (2009) di perairan Teluk Likupang, Sulawesi Utara menunjukkan pola pertumbuhan ikan layang biru bersifat alometrik positif. Pola pertumbuhan yang bersifat alometrik negatif hasil dari penelitian ini diduga karena ikan yang belum matang gonad banyak ditemukan pada lokasi sampling. Dominannya ikan yang belum matang gonad tersebut menunjukkan bahwa daerah penangkapan nelayan pukat cincin di perairan Laut Sulawesi merupakan daerah asuhan dan daerah mencari makan.

Perbedaan pola pertumbuhan ini diduga karena variasi ukuran ikan layang biru di Laut Sulawesi lebih besar/lebar, sebagaimana telah disebutkan sebelumnya. Faktor-faktor yang menyebabkan perbedaan pola pertumbuhan ikan selain perbedaan spesies adalah perbedaan jumlah dan variasi ukuran ikan yang diamati, tahap perkembangan ikan, jenis kelamin dan faktor lingkungan serta perkembangan ontogenetiknya (Türkmen et al., 2002). Hal senada juga disebutkan oleh Ricker (1975), bahwa perbedaan ini terjadi karena pengaruh faktor ekologis dan 
biologis. Keadaan lingkungan yang sering berubah atau kondisi dari ikannya juga berubah maka hubungan panjang - berat akan sedikit menyimpang dari $b=3$ (Merta, 1993). Effendie (2002) mengatakan bahwa nilai b berhubungan dengan kondisi ikan, sedangkan kondisi ikan bergantung pada makanan, umur, jenis kelamin dan kematangan gonad.

Perbandingan ikan yang berjenis kelamin jantan dan betina biasa disebut dengan nisbah kelamin. Kondisi yang baik (ideal) adalah nisbah kelamin berada pada keadaan seimbang (Nababan dalam Makmur \& Prasetyo, 2006), atau ikan betina lebih banyak daripada ikan jantan, perbandingan jantan dan betina adalah jantan : betina $=1$ : e"1 (Wahyuono et al., 1983). Kestabilan suatu populasi ikan dapat diketahui dengan adanya perbandingan antara ikan jantan dan betina. Nisbah kelamin ikan layang biru pada penelitian ini antara jantan : betina $=1,963: 1$, artinya ikan jantan lebih banyak dari ikan betina. Nilai perbandingan ini dapat disebabkan karena perbedaan pola tingkah laku ikan jantan dan betina, laju mortalitas yang berbeda (Bal \& Rao, 1984). Nikolsky (1963) menyatakan bahwa aktifitas selama pemijahan dapat mempengaruhi nilai nisbah kelamin, pada awal pemijahan umumnya didominasi oleh ikan jantan, kemudian jumlah jantan dan betina seimbang saat terjadi pemijahan, dan selanjutnya akan didominasi oleh ikan betina sampai pemijahan selesai. Selektivitas alat tangkap, musim dan daerah penangkapan dapat menyebabkan adanya variasi nisbah kelamin (Widodo et al., 1993). Nisbah kelamin ikan layang biru di perairan Teluk Tomini berbeda dengan penelitian ini, nisbah kelamin ikan layang biru di Teluk Tomini antara ikan jantan dan betina relatif sama (Widiyastuti \& Zamroni, 2017).

Pengamatan terhadap kematangan gonad menunjukkan bahwa ikan yang tertangkap didominasi oleh ikan dalam kondisi kematangan tingkat III, artinya gonad masih dalam kondisi berkembang. Hal ini mempertegas bahwa daerah penangkapan nelayan pukat cincin di perairan Laut Sulawesi bukan merupakan daerah pemijahan ikan. Pada bulan Februari ditemukan ikan dalam kondisi matang gonad, meskipun harus didukung oleh data yang lebih banyak, dapat diduga bahwa pada bulan tersebut merupakan salah satu waktu musim pemijahan ikan layang biru. Secara umum, ikan pelagis kecil memijah sepanjang tahun dan puncak pemijahan dapat diduga dengan melihat persentase yang tinggi dari tingkat kematangan gonad yang sudah matang (Effendie, 2002).

Nilai indeks gonad hasil penelitian selama 11 bulan berada pada kisaran 0,08-7,2\%. Ditinjau dari kematangan gonadnya, nilai indeks gonad rata-rata pada saat TKG I adalah sekitar $0,37 \%$, nilai indeks gonad rata-rata pada saat TKG II adalah sekitar 1,13\%, sedangkan nilai indeks gonad rata-rata pada TKG III dan IV masing-masing adalah $2,82 \%$ dan $4,2 \%$. Hal ini menunjukkan bahwa peningkatan nilai indeks gonad seiring dengan meningkatnya TKG. Hal ini disebabkan meningkatnya TKG disertai dengan bertambah besar ukuran gonad ikan, diameter telur dalam gonad juga semakin besar, sehingga hal ini dapat meningkatkan nilai indeks gonad. Setiap bulan nilai indeks gonad berfluktuasi dan mengalami peningkatan maksimum ketika ikan akan memijah. Fluktuasi kumulatif indeks gonad memperlihatkan tiga kali periode indeks gonad yang lebih rendah. Periode ini menunjukkan bahwa ikan layang biru diduga terjadi puncak musim pemijahan. Nilai indeks gonad ini semakin mempertegas bahwa bulan Maret merupakan salahsatu bulan dimana terjadi puncak musim pemijahan ikan layang biru. Hasil ini berbeda dengan hasil penelitian yang dilakukan oleh Widiyastuti \& Zamroni (2017), Zamroni et al. (2013) dan Zamroni \& Suwarso (2011) pada spesies yang sama dengan perairan yang berbeda (Teluk Tomini, Sekitar Sulawesi dan Laut Banda), dengan puncak musim pemijahan terjadi pada bulan Agustus. Sedangkan Seiji et al. (2014) menduga bahwa musim pemijahan ikan layang biru di timur Laut China berlangsung pada bulan April-Juli. Shiraishi et al. (2010), Ohshimo et al. (2006) dan McBride et al. (2002) menduga bahwa terjadinya perbedaan puncak musim pemijahan disebabkan karena karakter habitat hidup ikan yang berbeda.

Hasil analisis panjang pertama kali matang gonad (Lm) ikan layang biru pada penelitian ini lebih rendah daripada penelitian sebelumnya yang dilakukan oleh Shiraishi et al. (2010) di perairan Selatan Kyushu, Jepang, Fadila et al. (2016) di perairan sekitar Kendari, Widiyastuti \& Zamroni (2017) di perairan Teluk Tomini dan Wulan (2017) di perairan selatan Blitar, Jawa Timur dengan nilai masingmasing pada panjang cagak $25,83 \mathrm{~cm}, 24,7 \mathrm{~cm}, 26,94$ dan $26,11 \mathrm{~cm}$. Ghosh et al. (2016) menyatakan bahwa perbedaan nilai Lm ini karena pengaruh dari perbedaan lingkungan laut dimana ikan tersebut berada, perubahan lingkungan terutama pada suhu dapat menyebabkan perbedaan nilai Lm (Karna \& Panda, 2011). Perbedaan lintang lebih dari $5^{\circ}$ dapat menyebabkan perbedaan pada umur dan nilai panjang pertama kali matang gonad (Effendie, 2002). Udupa (1986) menyatakan bahwa ikan dengan umur dan panjang yang sama tidak harus mencapai panjang matang gonad yang sama pula. Nilai panjang rata-rata tertangkap (L50\%) pada penelitian ini lebih besar dari penelitian yang dilakukan oleh Widiyastuti \& Zamroni (2017) di perairan Teluk Tomini, yaitu pada panjang cagak $24,31 \mathrm{~cm}$. Hargiyatno et al. (2013) berpendapat bahwa terdapat tiga faktor yang menyebabkan terjadinya perbedaan nilai L50\%. Faktor yang pertama adalah perbadaan mata jaring yang digunakan saat menangkap, yang kedua adalah waktu menangkap ikan (bulan atau musim) dan yang ketiga adalah daerah penangkapan (fishing ground). Menurut Erzini (1990), penggunaan data berbasis panjang ikan mempunyai beberapa keterbatasan, diantaranya adalah ukuran sampel dan lebar interval, sehingga hal ini dapat menyebabkan perbedaan nilai L50\%. Perbandingan nilai 
L50\% dan Lm yang diperoleh dalam penelitian ini menunjukkan bahwa nilai panjang pertama kali matang gonad lebih rendah daripada nilai panjang rata-rata tertangkap (L50\% > Lm). Hal ini mengindikasikan bahwa secara umum ikan telah mengalami matang gonad sebelum ikan tersebut ditangkap, sehingga proses rekruitmen belum terganggu oleh aktivitas penangkapan. Dapat diduga pula bahwa ikan berukuran kecil (ikan yang belum matang gonad) mempunyai tempat hidup yang berbeda dengan ikan yang telah dewasa.

Koefisien pertumbuhan adalah parameter yang menentukan seberapa cepat ikan mencapai panjang maksimumnya (Sparre \& Venema, 1998). Ikan yang memiliki koefisien pertumbuhan tinggi umumnya memiliki umur yang lebih pendek (Pauly, 1980). Nilai parameter pertumbuhan dalam penelitian ini berbeda dari hasil penelitian yang dilakukan oleh Iksan \& Irham (2009) di perairan Maluku Utara, Hariati (2011) di perairan Kendari dan Silooy et al. (2019) di perairan Laut Banda. Hasil penelitian tentang parameter pertumbuhan pada perairan lain tersebut dapat dilihat pada Tabel 2. Perbedaan dalam parameter pertumbuhan dapat disebabkan oleh perbedaan periode pengambilan sampel, ukuran sampel ikan dan daerah penangkapan ikan (Moazzam et al., 2005). Menurut Widodo (1988), perbedaan parameter pertumbuhan lebih dipengaruhi oleh komposisi ukuran sampel daripada oleh metode yang digunakan. Jika sampel ikan didominasi oleh ikan ukuran kecil maka koefisien pertumbuhan yang lebih tinggi akan diperoleh, sebaliknya jika sampel ikan terdiri dari ikan yang lebih besar maka koefisien pertumbuhan yang lebih kecil akan diperoleh. Amin et al. (2015) mengatakan bahwa perbedaan dalam parameter pertumbuhan adalah karena usia, jenis kelamin, kematangan dan periode pengambilan sampel untuk spesies yang sama. Perbedaan dalam nilai parameter pertumbuhan (1,01 hingga 2,28) juga dapat disebabkan oleh perbedaan lokasi geografis, kondisi air, dan persediaan makanan (Effendie, 2002). Perbedaan dalam parameter lingkungan, ketersediaan makanan, predasi, eksploitasi dan jenis alat tangkap yang digunakan, mempengaruhi parameter pertumbuhan (Ghosh et al., 2016). Menurut Suwarso \& Wujdi (2015), perbedaan panjang maksimum dapat dipengaruhi oleh perbedaan kondisi habitat dan tekanan dari kegiatan penangkapan ikan di setiap perairan. Lebih lanjut, Suwarso \& Wujdi (2015) mengatakan bahwa habitat dengan kandungan gizi atau ketersediaan makanan alami yang cukup dapat mendukung pertumbuhan ikan yang optimal, sementara kegiatan penangkapan ikan intensif tidak memberikan peluang ikan untuk tumbuh lebih besar sehingga panjang maksimum menjadi lebih kecil.

Tabel 2. Paremeter pertumbuhan $\left(\mathrm{L}_{\infty}\right.$ dan $\left.\mathrm{K}\right)$ ikan layang biru di penelitian lain.

Table 2. $\quad$ Growth parameter ( $L_{\infty}$ dan $K$ ) of Mackerel Scad in other study.

\begin{tabular}{cccll}
\hline No & L $\infty(\mathbf{c m})$ & K (tahun & \multicolumn{1}{|c}{ Lokasi } & \multicolumn{1}{c}{ Referensi } \\
\hline $\mathbf{1}$ & 33,57 & 0,39 & Maluku Utara & Iksan \$ Irham (2009) \\
$\mathbf{2}$ & 35,98 & 0,92 & Kendari & Hariati (2011) \\
$\mathbf{3}$ & 33,35 & 0,56 & Laut Banda & Silooy et al. $(2019)$ \\
$\mathbf{4}$ & 34,5 & 0,81 & Laut Sulawesi & Penelitian ini \\
\hline
\end{tabular}

Sebagaimana dengan hasil parameter pertumbuhan, hasail analisis mengenai mortalitas ikan layang biru di Laut Sulawesi juga berbeda dengan perairan lainnya. Misalnya hasil penelitian yang dilakukan oleh Hariati (2011) di perairan Kendari menghasilkan nilai mortalitas alami adalah 1,34 per tahun, nilai mortalitas total adalah 2,68 pertahun dan nilai mortalitas akibat peangkapan adalah sebesar 1,34 per tahun. Adanya perbedaan nilai mortalitas akibat penangkapan ikan tersebut dapat disebabkan oleh perbedaan distribusi ukuran ikan atau kelompok umur, terutama karakteristik distribusi ikan pelagis kecil seperti ikan layang yang bermigrasi baik temporal maupun spasial, dan kebiasaan ikan yang tersebar secara bergerombol. Selain itu, koefisien mortalitas terkait dengan penangkapan ikan umumnya dipengaruhi oleh jumlah alat tangkap dan intensitasnya; semakin tinggi jumlah alat tangkap yang mempunyai intensitas yang lebih tinggi berdampak pada koefisien mortalitas menjadi lebih besar. Sedangkan menurut Koolkalya et al. (2017), perbedaan angka kematian disebabkan oleh stok yang berbeda dengan tekanan penangkapan ikan yang berbeda terhadap parameter populasi. Nilai mortalitas akibat penangkapan dalam penelitian ini (1,2 per-tahun) lebih tinggi daripada nilai kematian alaminya ( 1,1 per-tahun), hal ini mengindikasikan bahwa ikan layang biru dalam penelitian ini telah mangalami tekanan penangkapan yang tinggi. Berdasarkan Sparre \& Venema (1998), tingginya nilai mortalitas akibat penangkapan ikan dan rendahnya nilai mortalits alami dapat mengindikasikan terjadinya kondisi penangkapan ikan yang berlebih. Oleh karena itu perlu dilakukan usaha untuk mencapai kondisi optimal, yaitu nilai mortalitas akibat penangkapan yang seimbang dengan nilai mortalitas alami, misalnya dengan melakukan pengurangan terhaap tekanan penangkapan.

Nilai E, atau tingkat eksploitasi dari ikan layang biru didapatkan dari perbandingan antara niali mortalitas akibat penangkapan (F) dengan nilai mortalitas total $(\mathrm{Z})$, yaitu sebesar 0,53 , yang mempunyai arti bahwa $53 \%$ mortalitas ikan layang biru di perairan Laut Sulawesi merupakan hasil dari kegiatan penangkapan ikan selama penelitian ini. Gulland (1971) mengemukakan bahwa ketika mortalitas 
alami dan mortalitas akibat penangkapan mempunyai nilai yang seimbang (yaitu, tingkat eksploitasi $(E)=0,5$ ), maka stok dalam keadaan sehat dan mengalami eksploitasi secara optimal. Tingkat eksploitasi dalam penelitian ini $(E=0,53)$ memiliki nilai yang lebih tinggi dari nilai eksploitasi optimal 0,5 per-tahun. Akan tetapi jika ditinjau dari sisi biologisnya, tingkat pemanfaatan ikan layang biru pada perairan ini selama penelitian masih cukup baik, karena nilai L50\% > Lm. Hal ini memiliki arti bahwa rata-rata ikan yang tertangkap sudah mengalami matang gonad. Disamping itu tingkat pertumbuhan ikan layang biru dalam penelitian ini lebih tinggi dari 0,5 $(\mathrm{K}>0,5)$. Menurut Sparre \& Venema (1998) ikan dengan koefisien laju pertumbuhan rendah akan membutuhkan waktu yang lebih lama untuk mencapai panjang maksimumnya dan ikan yang memiliki nilai laju pertumbuhan tinggi membutuhkan waktu lebih cepat untuk mencapai panjang maksimumnya. Semakin cepat ikan mencapai ukuran maksimum, maka semakin cepat pula ikan mencapai ukuran gonad dewasa (matang gonad) dan pemijahan, sehingga perekrutan ikan tidak banyak terganggu meskipun tingkat eksploitasi tinggi.

Berdasarkan hasil analisis kurva pertumbuhan dapat diketahui bahwa ikan layang biru pada umur 6, 12 dan 24 bulan panjang cagak ikan masing-masing adalah $11,6 \mathrm{~cm}$, $19,1 \mathrm{~cm}$ dan $27,6 \mathrm{~cm}$. Umur ikan saat mencapai panjang asimptotiknya $\left(\mathrm{L}_{\infty}=34,5 \mathrm{~cm}\right)$ adalah sekitar 45 bulan $(3,75$ tahun). Ikan layang biru yang dominan tertangkap di perairan Laut Sulawesi umumnya mempunyai umur sekitar 22,5 bulan, atau berada pada ukuran $26,89 \mathrm{~cm}$ pada panjang cagaknya.

\section{KESIMPULAN}

Sebaran ukuran panjang ikan layang biru pada kisaran panjang cagak 10,25 - 32,25 cm. Pengamatan nisbah kelamin menunjukkan bahwa nisbah kelamin ikan layang biru pada penelitian ini ikan jantan : ikan betina $=1,963: 1$ (kondisi kurang baik atau kurang ideal). Ikan layang biru yang tertangkap didominasi oleh ikan dalam kondisi kematangan tingkat III dengan kondisi gonad dalam kondisi berkembang. Nilai panjang pertama kali matang gonad lebih rendah daripada nilai panjang rata-rata tertangkap (L50\% > Lm) yang mengindikasikan ikan telah mengalami matang gonad sebelum ikan tersebut ditangkap, sehingga proses rekruitmen belum terganggu oleh aktivitas penangkapan. Akan tetapi tingkat pemanfaatan lebih dari 0,5 $(E=0,52)$, sehingga perlu hatihati dalam eksploitasinya, misalnya dengan pembatasan daerah penangkapan supaya tidak terlalu mendekati daratan yang diduga merupakan tempat hidup bagi ikanikan yang belum dewasa.

\section{PERSANTUNAN}

Tulisan ini merupakan hasil dari kegiatan Penelitian Sumberdaya Ikan di WPP 716 (Laut Sulawesi) di Balai Riset Perikanan Laut Tahun 2016 - 2018. Penulis mengucapkan terimakasih kepada teman-teman di PSDKP Tumumpa, Manado yang telah membantu dalam pengumpulan sampel. Dalam karya tulis ilmiah ini Achmad Zamroni adalah sebagai kontributor utama.

\section{DAFTAR PUSTAKA}

Akerina, I. M. F., Pratasik, S. B., \& Bataragoa, N. E. (2019) Pola Pertumbuhan Ikan Layang (Decapterus spp) di Perairan Likupang, Sulawesi Utara. Jurnal Ilmiah Platax. 7(1), 113-130. DOI: https://doi.org/10.35800/ jip.7.1.2019.22593

Ambarwati, D. V. S. (2008). Studi Biologi Reproduksi Ikan Layur (Superfamili Trichiuroidea) Di Perairan Palabuhanratu, Kabupaten Sukabumi, Jawa Barat. Skripsi. Fakultas Perikanan Dan Ilmu Kelautan Institut Pertanian Bogor, Bogor.

Amin, A. M., Sabrah, M. M., El-Ganainy, A., \& El-Sayed, A. Y. (2015). Population structure of Indian mackerel, Rastrelliger kanagurta (Cuvier, 1816), from the Suez Bay, Gulf of Suez, Egypt. Int. J. Fish. Aquat. Stud., 3(1), 68-74. DOI: http://dx.doi.org/10.22271/fish

Ball, D.V., \& Rao, K.V. (1984). Marine fisheries (p. 51-73). New Delhi: Tata Mc. Graw-Hill Publishing Company, Limited.

Donaldson, W. E., \& Donaldson, W. K. (1992). A review of the history and justification for size limits in Alaskan king, tanner, and snow crab fisheries. Fish. Res. Bull. 92-02, 22. URI: http://www.sf.adfg.state.ak.us/ fedaidpdfs/FRB.1992.02.pdf

Effendie, I. M. (2002). Biologi Perikanan (p. 163). Bogor: Yayasan Pustaka Nusantara.

Erzini, K. (1990). Sample size and grouping of data for length-frequency analysis. Fish. Res., 9, 355-366. DOI: https://doi.org/10.1016/0165-7836(90)90053-X

Fadila, M., Asriyana, A., \& Tadjuddah, M. (2016). Beberapa aspek biologi reproduksi Ikan Layang (Decapterus macarellus) hasil tangkapan Purse Seine yang didaratkan di Pelabuhan Perikanan Samudera Kendari. Jurnal Manajemen Sumber Daya Perairan, 1(4), 343353. URI: http://ojs.uho.ac.id/index.php/JMSP/article/ download/2480/1833 
Ghosh S, Rao, M. V. H., Mahesh, V. U., Kumar, M. S., \& Rohit, P. (2016). Fishery, Reproductive Biology and Stock Status of the Indian Mackerel Rastrelliger kanagurta (Cuvier, 1817), Landed Along the Northeast Coast of India. Indian Journal Fish. 63(2), 33-41. DOI: 10.21077/ijf.2016.63.2.53399-05

Gulland, J. A. (1971). Fish Resources of the Ocean (p. 255). London: Fishing New Books.

Hargiyatno, I. T., Sumiono, B., \& Suharyanto, S. (2013). Catch rate, stock density and some biological aspect of white prawn (Penaeus merguensis) in Dolak wat rs, Arafura Seas. Bawal, 5(2), 123-129. DOI: http:// dx.doi.org/10.15578/bawal.5.2.2013.123-129

Hariati, T. (2011). Tingkat pemanfaatan ikan layang abuabu (Decapterus macrosoma) dan Layang Biru (Decapterus macarellus) dari Perairan Kendari. J.Lit.Perikan.Ind. 17(1), 31-40. DOI: http://dx.doi.org/ 10.15578/jppi.17.1.2011.31-40

Iksan, K. H., \& Irham. (2009). Pertumbuhan dan Reproduksi Ikan Layang Biru (Decapterus macarellus) di Perairan Maluku Utara. Jurnal Iktiologi Indonesia. 9 (2), 163 174. DOI: https://doi.org/10.32491/jii.v9i2.191

Jørgensen, C. K., Enberg, E. S., Dunlop, R., Arllinghaus, D. S., Boukal, K., Brander, B., \& Ernande, A. (2007). Ecology-managing evolving fish stocks. Science. 318, 1247-1248. DOI: 10.1126/science.1148089

Karna S. K., \& Panda, S. (2011). Growth estimation and length at maturity of a commercially important fish species i. e., Dayscieaena albida (Boroga) in Chilika Lagoon, India. Euro. J. Exp. Bio., 1(2), 8491. URI: http://www.imedpub.com/articles/growth-estimationand-length-at-maturity-of-a-commercially-importantfishspecies-i-e-idayscieaena-albidai-boroga-inchilika-lagoon.pdf

Koolkalya, S., Matchakuea, U., \& Jutagate, T. (2017). Growth, population dynamics and optimum yield of indian mackerel, Rastrelliger kanagurta (Cuvier, 1816), in the eastern Gulf of Thailand. IJAT., 13(7.1), 1065-1075. URI: https://pdfs.semanticscholar.org/ ebe7/4f4b1a79593ff27bdd930237dae5b0ca5cf0. pdf?_ga $=2.172871013 .712079523 .1580710670$ 1360567499.1580303336

Makmur, S., \& Prasetyo, D. (2006). Kebiasaan Makan, Tingkat Kematangan Gonad, dan Fekunditas Ikan Haruan (Channa striata Bloch), di Suaka PerIkanan Sungai Sambujur, DAS Barito, Kalimantan Selatan. Jurnal Ilmu-Ilmu Perikanan dan Kelautan
Indonesia. 13(1), 27-31. URI: https://journal.ipb.ac.id/ index.php/jippi/article/view/11951/9266

Manik, N. (2009). Hubungan panjang berat dan faktor kondisi ikan layang (Decapterus russelli) dari perairan sekitar Teluk Likupang, Sulawesi Utara. Oseanologi dan Limnologi di Indonesia. 35(1), 65-74. DOI: https:/ /doi.org/10.5072/FK2/JORY1A

McBride, R. S., Stengard, F. J., \& Mahmoudi, B. (2002) Maturation and diel reproductive periodicity of round scad (Carangidae: Decapterus punctatus). Mar. Biol. 140,713-722. DOI: 10.1007/s00227-001-0759-4

Merta, I. G. S. (1993). Hubungan panjang - berat dan factor kondisi ikan lemuru, Sardinella lemuru Bleeker, 1853 dari perairan Selat Bali. Jur. Pen. Per. Laut. 73, 35 - 44.

Moazzam, M., Osmany, H. B., \& Zohra, K. (2005). Indian mackerel (Rastrelliger kanagurta) from Pakistan. Some aspects of biology and fisheries. Rec. Zool. Surv. Pakistan, 16, 58-75.

Nikolsky, G.V. (1963). The ecology of fishes. NewYork: Academic Press.

Ongkers, O. T. S., Pattikawa, J. A., \& Rijoly, F. (2016). Apek Biologi Ikan Layang (Decapterus russelli) di Peairan Latuhalat, Kecamatan Nusaniwe, Pulau Ambon. OmniAkuatika. 12(3), 79-87. DOI: 10.20884/ 1.oa.2016.12.3.128

Ohshimo, S., Yoda, M., Itasaka, N., \& Ichimaru, T. (2006) Age, growth and reproductive characteristics of round scad Decapterus maruadsi in the waters off west Kyushu, the East China Sea. Fish. Sci. 72, 855-859. DOI: 10.1111/j.1444-2906.2006.01227.x

Pollock, S. C. (1995). Changes in maturation ages and sizes in crustacean and fish populations. S. Afr. J. Mar. Sci. 15, 99-103. DOI: https://doi.org/10.2989/ 02577619509504836

Pauly, D. (1980). On the interrelationships between natural mortality, growth parameters and mean environmental temperature in 175 fish stocks. Journal of Conservation and Exploring Meridien, 39, 175-192. DOI: https://doi.org/10.1093/icesjms/39.2.175

Paully, D. (1984). Fish population dynamics in Tropical Waters: A Manual for Use With Programable Calculators (p. 325). Manila: ICLARM.

Ricker, W. E. (1975). Computation and interpretation of biological statistics of fish populations. Fish. Res. 
Bd. Can. Bull. 191, 382. URI: https://www.dfompo.gc.ca/Library/1485.pdf

Seiji, O., Shiraishi, T., Tanaka, H., Yasuda, T., Yoda, M., Ishida, H., \& Tomiyasu, S. (2014). Growth and reproductive characteristics of the roughear scad Decapterus tabl in the East China Sea. JARQ. 48 (2), 245-252. DOI: 10.6090/jarq.48.245

Shiraishi, T., Tanaka, H., Ohshimo, S., Ishida, H., \& Morinaga, N. (2010). Age, Growth and Reproduction of Two Species of Scad, Decapterus macrosoma and D. macarellus in the Waters off Southern Kyushu. JARQ. 44(2), 197-206. DOI: https://doi.org/10.6090/ jarq.44.197

Silooy, F. D., Tupamahu, A., Ongkers, O. T. S., \& Haruna, H. (2019) Population Dynamics of Mackerel Scad (Decapterus macarellus) in the Banda Sea. International Journal of Environment, Agriculture and Biotechnology. 4(4), 1199-1204. DOI: 10.22161/ ijeab/4446

Sokal, R.R., \& Rohlf, F.J. (1987). Introduction to biostatistics, 2nd edn (pp. 160-184). New York: Freeman Publication.

Sparre, P., \& Venema, S. C. (1998). Introduction to tropical fish stock assessment. Part 1: manual. FAO Fish. Tech. Paper. No. 306.1, Rev. 2 (p. 407). Rome: FAO.

Stearns, S. C. (1992). The evolution of life histories (p. 249). Oxford: University Press, Oxford.

Suwarso, S., \& Wujdi, A. (2015). Population dynamic and spawning potential ratio of bali sardinella (Sardinella lemuru Bleeker, 1853) in the Prigi Bay, East Java. J. Lit. Perikan. Ind., 21(3), 177-186. DOI: http:// dx.doi.org/10.15578/jppi.21.3.2015.177-186

Türkmen, M., Erdogan, O., Yildirim, A., \& Akhyurt, I. (2002). Reproductive tactics, age and growth of Capoeta capoeta umla Heckel 1843 from the Askale Region of theKarasu River, Turkey. Journal Of Fsheries Research. 54, 317-328. DOI: https://doi.org/10.1016/ S0165-7836(01)00266-1

Udupa, K. S. (1986). Statistical method of estimating the size at first maturity in fishes. ICLARM, Metro Manila, Fishbyte. 4(2), 8-10. URL: http://pubs.iclarm.net/Naga/ na_2900.pdf
Wahyuono, H., Budihardjo, S., Wudianto, W., \& Rustam, R. (1983). Pengamatan parameter biologi beberapa jenis ikan demersal di perairan Selat Malaka, SumateraUtara. Laporan Penelitian Perikanan Laut. 26, 29-48

Watters, G., \& Hobday, A. J. (1998). A new method for estimating the morphometric size at maturity of crabs. Can. J. Fish. Aquat. Sci. 55,704-714 DOI: https:// doi.org/10.1139/f97-266

Widiyastuti, H., \& Zamroni, A. (2017). Biologi Reproduksi Ikan Layang biru (Decapterus macarellus Cuvier, 1833) di Teluk Tomini. Bawal. 9(1), 63-71. DOI: http:// dx.doi.org/10.15578/bawal.9.1.2017.63-72

Widodo, J. (1988). Population Dynamics and Management of Ikan layang (Decapterus spp) (Carangidae) in the Java Sea. Jurnal Penelitian Perikanan Laut, 47, 1144.

Widodo, J., Suwarso., \& Basuki, R. (1993). Kajian pendahuluan terhadap biologi dan perikanan Ikan Siro, Amblygaster sirm (Clupeidae) di Laut Jawa. Jurnal Penelitian Perikanan Laut. 72, 21-31.

Widodo, J., \& Suadi. (2006). Pengelolaan Sumber Daya Perikanan Laut (p. 252). Yogyakarta: Gadjah Mada Universitas Press.

Wulan, A. N. (2017). Dinamika Populasi Ikan Layang Biru (Decapterus macarellus Cuvier, 1833) yang Didaratkan di Instalasi Pelabuhan Perikanan (IPP) Tambakrejo Kabupaten Blitar Jawa Timur. Skripsi. Fakultas Perikanan dan Ilmu Kelautan Universitas Brawijaya Malang

Zamroni, A., \& Suwarso. (2011). Studi tentang biologi reproduksi beberapa spesies ikan pelagis kecil di perairan Laut Banda. BAWAL. 3 (5), 337-334. DOI: http://dx.doi.org/10.15578/bawal.3.5.2011.337-344

Zamroni, A., Fauzi, Moh., \& Kuswoyo, A. (2013). Status pemanfaatan sumberdaya ikan di perairan Laut Sulawesi. Kajian Biologi dan Parameter Populasi Ikan Layang Biru (Decapterus macarellus) di Laut Sulawesi (pp. 39-52). Jakarta: IPB Press dan Kementerian Kelautan dan Perikanan. 